\title{
Sodium-Promoted $\mathrm{Pd} / \mathrm{TiO}_{2}$ for Catalytic Oxidation of Formaldehyde at Ambient Temperature
}

\author{
Changbin Zhang, ${ }^{\dagger}$ Yaobin $\mathrm{Li}^{\dagger}{ }^{\dagger}$ Yafei Wang, and Hong $\mathrm{He}^{*}$
}

Research Center for Eco-Environmental Sciences, Chinese Academy of Sciences, Beijing 100085, China

\author{
Supporting Information
}

ABSTRACT: Catalytic oxidation of formaldehyde ( $\mathrm{HCHO}$ ) to $\mathrm{CO}_{2}$ at ambient conditions is of great interest for indoor $\mathrm{HCHO}$ purification. Here, we report that sodium-doped $\mathrm{Pd} /$ $\mathrm{TiO}_{2}$ is a highly effective catalyst for the catalytic oxidation of $\mathrm{HCHO}$ at room temperature. It was observed that $\mathrm{Na}$ doping has a dramatic promotion effect on the $\mathrm{Pd} / \mathrm{TiO}_{2}$ catalyst and that nearly $100 \% \mathrm{HCHO}$ conversion could be achieved over the $2 \mathrm{Na}-\mathrm{Pd} / \mathrm{TiO}_{2}$ catalyst at a GHSV of $95000 \mathrm{~h}^{-1}$ and $\mathrm{HCHO}$ inlet concentration of $140 \mathrm{ppm}$ at $25{ }^{\circ} \mathrm{C}$. The
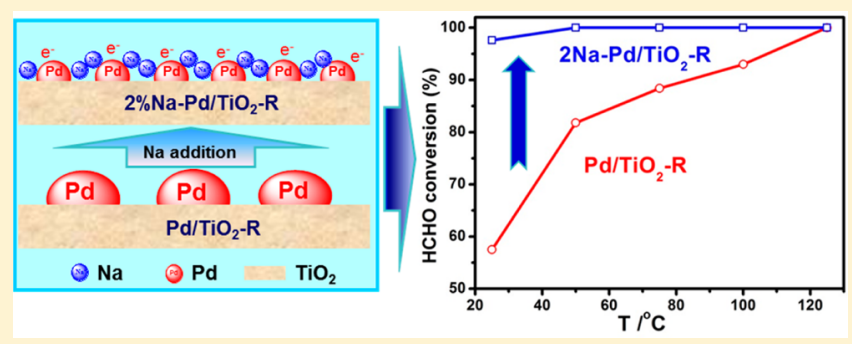
mechanism of the Na-promotion effect was investigated by using Brunauer-Emmett-Teller (BET), X-ray diffraction (XRD), CO chemisorption, Temperature-programmed reduction by $\mathrm{H}_{2}\left(\mathrm{H}_{2}\right.$-TPR), X-ray photoelectron spectroscopy (XPS) and temperature-programmed desorption of $\mathrm{O}_{2}\left(\mathrm{O}_{2}-\mathrm{TPD}\right)$ methods. The results showed that $\mathrm{Na}$ species addition can induce and further stabilize a negatively charged and well-dispersed Pd species, which then facilitates the activation of $\mathrm{H}_{2} \mathrm{O}$ and chemisorbed oxygen, therefore resulting in the high performance of the $2 \mathrm{Na}-$ $\mathrm{Pd} / \mathrm{TiO}_{2}$ catalyst for the ambient $\mathrm{HCHO}$ destruction.

\section{INTRODUCTION}

The "sick building syndrome" has become a critical issue in most new houses as a result of increasing concerns about indoor air pollutants. ${ }^{1}$ Formaldehyde (HCHO) emitted from building/furnishing materials and consumer products is recognized as a major indoor air pollutant in airtight houses and is known to cause nasal tumors, irritation of the mucous membranes of the eyes and respiratory tract, and skin irritation. ${ }^{2,3}$ Therefore, in order to improve indoor air quality and reduce public health risk, the effective abatement of indoor air $\mathrm{HCHO}$ is urgently needed.

Over the past decades, researchers have focused on four technologies for the removal of HCHO: adsorption, photocatalysis, plasma technology, and catalytic oxidation. ${ }^{4-9}$ The adsorption is a useful method for indoor air HCHO removal. Some absorbents can successfully reduce indoor $\mathrm{HCHO}$ concentrations to very low levels; ${ }^{4}$ however, their effectiveness is limited by adsorption capacities and the secondary pollution during regeneration. The catalytic oxidation method can selectively decompose the low concentration toxic $\mathrm{HCHO}$ to harmless $\mathrm{CO}_{2}$ over some catalysts at ambient temperature without the need of energy input. ${ }^{9,10}$ Therefore, the catalytic oxidation is regarded as the most promising method for indoor air HCHO removal. ${ }^{9,10}$

The conventional catalysts for $\mathrm{HCHO}$ oxidation include transition-metal oxides $(\mathrm{Ni}, \mathrm{Co}, \mathrm{Ag} \text {, and } \mathrm{Mn})^{11-17}$ and the supported noble metal $(\mathrm{Pt}, \mathrm{Pd}, \mathrm{Rh}$, and $\mathrm{Au})$ catalysts. ${ }^{18-28}$ The transition-metal oxides generally need much high temperatures $\left(>150{ }^{\circ} \mathrm{C}\right)$ to achieve complete oxidation of $\mathrm{HCHO}$. In contrast, the noble metal catalysts such as Pt-, Pd-, and Au- based catalysts have exhibited excellent activity for catalytic oxidation of $\mathrm{HCHO}$ at around $25{ }^{\circ} \mathrm{C}^{18,20-23,26-28}$ and, therefore, are more suitable for indoor air $\mathrm{HCHO}$ purification.

Previuosly, we have developed a $\mathrm{Pt} / \mathrm{TiO}_{2}$ catalyst for $\mathrm{HCHO}$ catalytic oxidation, achieving $100 \%$ conversion of $100 \mathrm{ppm}$ of $\mathrm{HCHO}$ to $\mathrm{CO}_{2}$ and $\mathrm{H}_{2} \mathrm{O}$ at a gas hourly space velocity (GHSV) of $50000 \mathrm{~h}^{-1}$ at room temperature. ${ }^{20-22}$ Then, we further demonstrated that the addition of alkali ions (such as $\mathrm{Li}^{+}, \mathrm{Na}^{+}$, and $\mathrm{K}^{+}$) could dramatically promote the catalytic efficacy of $\mathrm{Pt} / \mathrm{TiO}_{2}$ catalyst by inducing and stabilizing an atomically dispersed $\mathrm{Pt}$ species. ${ }^{26} \mathrm{We}$ also proposed that this promotion effect of alkali ions on Pt catalysts may apply to other noble-metal-based catalysts. ${ }^{26}$ Instead of Pt-based catalysts, Pd-based catalysts are much less expensive and will have more extensive application for indoor air $\mathrm{HCHO}$ purification. Therefore, it is worth exploring whether the Napromotion effect for $\mathrm{Pt}$ is also manifested for Pd catalysts.

In this paper, we prepared $\mathrm{Pd} / \mathrm{TiO}_{2}$ catalysts with and without sodium $(\mathrm{Na})$ addition and tested their catalytic activities in $\mathrm{HCHO}$ oxidation at low temperature. It was verified that the $\mathrm{Na}$ addition also had a dramatic promotion effect on the Pd-based catalyst. $\mathrm{Na}-\mathrm{Pd} / \mathrm{TiO}_{2}(2 \mathrm{wt} \%)$ showed much higher performance in ambient $\mathrm{HCHO}$ oxidation than the Na-free catalyst, achieving $100 \%$ conversion of $140 \mathrm{ppm}$ of $\mathrm{HCHO}$ to $\mathrm{CO}_{2}$ and $\mathrm{H}_{2} \mathrm{O}$ at a gas hourly space velocity

Received: December 19, 2013

Revised: April 15, 2014

Accepted: April 16, 2014

Published: April 16, 2014 
Table 1. Bulk Composition, Specific Surface Area (BET), Average Pore Size (d), and Total Pore Volume (V) of Pd/TiO $\mathbf{V}_{2}$ and $2 \mathrm{Na}-\mathrm{Pd} / \mathrm{TiO}_{2}$ Catalysts together with $\mathrm{TiO}_{2}$, and Pd Dispersion (D) and Metal Size on $\mathrm{Pd} / \mathrm{TiO}_{2}-\mathrm{R}$ and $2 \mathrm{Na}-\mathrm{Pd} / \mathrm{TiO}{ }_{2}-\mathrm{R}$ catalysts

\begin{tabular}{|c|c|c|c|c|c|c|c|}
\hline \multirow[b]{2}{*}{ sample } & \multicolumn{2}{|c|}{ bulk comp ${ }^{a}$ (wt \%) } & \multirow[b]{2}{*}{$\operatorname{BET}\left(\mathrm{m}^{2} / \mathrm{g}\right)$} & \multirow[b]{2}{*}{$d_{\mathrm{p}}(\mathrm{nm})$} & \multirow[b]{2}{*}{$V\left(\mathrm{~cm}^{3} / \mathrm{g}\right)$} & \multirow[b]{2}{*}{$D_{\mathrm{co}}^{b}(\%)$} & \multirow[b]{2}{*}{$\operatorname{metal~size}^{c} d_{\mathrm{m}}(\mathrm{nm})$} \\
\hline & $\mathrm{Pd}$ & $\mathrm{Na}$ & & & & & \\
\hline $\mathrm{TiO}_{2}$ & & & 58.9 & 28.2 & 0.43 & & \\
\hline $\mathrm{Pd} / \mathrm{TiO}_{2}$ & 0.99 & & 56.5 & 28.1 & 0.40 & & \\
\hline $\mathrm{Pd} / \mathrm{TiO}_{2}-\mathrm{R}$ & & & 53.1 & 28.7 & 0.38 & 9.8 & 11.4 \\
\hline $2 \mathrm{Na}-\mathrm{Pd} / \mathrm{TiO}_{2}$ & 0.95 & 1.95 & 46.5 & 31.7 & 0.37 & & \\
\hline $2 \mathrm{Na}-\mathrm{Pd} / \mathrm{TiO}_{2}-\mathrm{R}$ & & & 56.9 & 26.8 & 0.38 & 32.9 & 3.4 \\
\hline
\end{tabular}

(GHSV) of $95000 \mathrm{~h}^{-1}$ at $25^{\circ} \mathrm{C}$. Based on the characterization results, the mechanism of Na-promotion effect on the $\mathrm{Pd} / \mathrm{TiO}_{2}$ catalyst was clearly elucidated.

\section{EXPERIMENTAL SECTION}

Materials Preparation. The 1 wt $\% \mathrm{Pd} / \mathrm{TiO}_{2}, 2$ wt \% Na/ $\mathrm{TiO}_{2}$, and 2 wt $\% \mathrm{Na}-1$ wt $\% \mathrm{Pd} / \mathrm{TiO}_{2}$ samples were prepared by co-impregnation of $\mathrm{TiO}_{2}$ (Degussa P25, BET surface area 59 $\left.\mathrm{m}^{2} \mathrm{~g}^{-1}\right)$ with aqueous $\mathrm{NaNO}_{3}$ and $\mathrm{Pd}\left(\mathrm{NO}_{3}\right)_{2}$ (Aldrich) for $1 \mathrm{~h}$. After impregnation, the excess water was removed in a rotary evaporator at $60{ }^{\circ} \mathrm{C}$. The samples were dried at $110{ }^{\circ} \mathrm{C}$ for $12 \mathrm{~h}$ and then calcined at $400{ }^{\circ} \mathrm{C}$ for $2 \mathrm{~h}$. The samples reduced with $\mathrm{H}_{2}$ at $350{ }^{\circ} \mathrm{C}$ for $30 \mathrm{~min}$ were denoted as $2 \mathrm{Na} / \mathrm{TiO}_{2}-\mathrm{R}, \mathrm{Pd} /$ $\mathrm{TiO}_{2}-\mathrm{R}$, and $2 \mathrm{Na}-\mathrm{Pd} / \mathrm{TiO}_{2}-\mathrm{R}$. The actual $\mathrm{Pd}$ and $\mathrm{Na}$ loading amounts in $\mathrm{Pd} / \mathrm{TiO}_{2}$ and $2 \mathrm{Na}-\mathrm{Pd} / \mathrm{TiO}_{2}$ were measured using inductively coupled plasma optical emission spectrometry (ICP-OES) (OPTIMA 8300, PerkinElmer), and the data are presented in Table 1.

Material Characterization. X-ray powder diffraction (XRD) patterns of the catalyst samples were collected with an X'Pert PRO MPD X-ray powder diffractometer with $\mathrm{Cu} \mathrm{K} \alpha$ radiation operated at $40 \mathrm{kV}$ and $40 \mathrm{~mA}$. The patterns were measured over the $2 \theta$ range from $10^{\circ}$ to $90^{\circ}$ at a scan step of $0.02^{\circ}$. The specific surface area and pore characterization of the catalysts was obtained at $-196{ }^{\circ} \mathrm{C}$ over the whole range of relative pressures, using a Quantachrome Quadrasorb SI-MP analyzer. Prior to the $\mathrm{N}_{2}$ physisorption, the catalysts were degassed at $300{ }^{\circ} \mathrm{C}$ for $5 \mathrm{~h}$. Specific surface areas were calculated from the isotherms by applying the BET equation in the $0.05-0.3$ partial pressure range.

$\mathrm{CO}$ chemisorption, $\mathrm{H}_{2}$ temperature-programmed reduction $\left(\mathrm{H}_{2}\right.$-TPR), and $\mathrm{O}_{2}$ temperature-programmed desorption $\left(\mathrm{O}_{2}-\right.$ TPD) were performed in a Micromeritics AutoChem II 2920 apparatus, equipped with a computer-controlled CryoCooler and a thermal conductivity detector (TCD).

CO chemisorption was measured by a dynamic pulse method. ${ }^{28}$ The samples (30 mg, 40-60 mesh) were reduced at $350{ }^{\circ} \mathrm{C}$ for $30 \mathrm{~min}$ in $10 \% \mathrm{H}_{2} / \mathrm{Ar}\left(50 \mathrm{~mL} \mathrm{~min}^{-1}\right)$, followed by flushing in $\mathrm{He}\left(50 \mathrm{~mL} \mathrm{~min} \mathrm{mi}^{-1}\right)$ for $30 \mathrm{~min}$. Then, the temperature was lowered to room temperature in $\mathrm{He}$ flow. Pulses of $5 \% \mathrm{CO} / \mathrm{He}$ were introduced to the catalyst until uptake saturation was obtained. The $\mathrm{CO}$ consumption was monitored by TCD. The dispersion of $\mathrm{Pd}$ was calculated assuming a CO/Pd stoichiometric ratio of $1 . .^{27,29}$ The crystallite sizes of the dispersed metals were estimated from the $\mathrm{CO}$ chemisorption data, using the relation $d_{\mathrm{M}}(\AA)=11.2 / D_{\text {co }}{ }^{30}$ where $d_{\mathrm{M}}$ is the mean crystallite diameter and $D_{\text {co }}$ is the dispersion of the metals.
For $\mathrm{H}_{2}-\mathrm{TPR}$, reduction profiles were obtained by passing a flow of $10 \% \mathrm{H}_{2} / \mathrm{Ar}$ at a rate of $50 \mathrm{~mL} \mathrm{~min}^{-1}$ (STP) through the sample (weight around $60 \mathrm{mg}$ ). The temperature was increased from -50 to $+450{ }^{\circ} \mathrm{C}$ at a rate of $10{ }^{\circ} \mathrm{C} \min ^{-1}$, and the $\mathrm{H}_{2}$ consumption was monitored by TCD after removal of produced $\mathrm{H}_{2} \mathrm{O}$.

For $\mathrm{O}_{2}$-TPD, the samples were first prereduced with $10 \%$ $\mathrm{H}_{2} / \mathrm{Ar}$ at $350{ }^{\circ} \mathrm{C}$ for $30 \mathrm{~min}$, followed by purging with $\mathrm{He}$ for $30 \mathrm{~min}$ to desorb $\mathrm{H}_{2}$. The temperature was then cooled down to $25{ }^{\circ} \mathrm{C}$, and then the gas was switched to $\mathrm{O}_{2}$ for adsorption for $30 \mathrm{~min}$. After that, He flowed for $1 \mathrm{~h}$ to remove weakly adsorbed $\mathrm{O}_{2}$. The temperature was increased to $400{ }^{\circ} \mathrm{C}$ at a heating rate of $10{ }^{\circ} \mathrm{C} \mathrm{min}^{-1}$.

$\mathrm{X}$-ray photoelectron spectra (XPS) were measured by an AXIS Ultra system, equipped with $\mathrm{Al} \mathrm{K} \alpha$ radiation $(h \nu=1486.6$ $\mathrm{eV}$ ) with an X-ray anode operated at $225 \mathrm{~W}$ and $15 \mathrm{kV}$. The $\mathrm{C}$ 1s peak $(284.8 \mathrm{eV})$ was used to calibrate the binding energy (BE) values. The surface relative composition was estimated from the integrated intensities corrected by atomic sensitivity factors.

Activity Test for Formaldehyde Oxidation. The activity tests for the catalytic oxidation of $\mathrm{HCHO}$ over the catalysts $(60$ $\mathrm{mg}$ ) were performed in a fixed-bed quartz flow reactor (i.d. $=4$ $\mathrm{mm}$ ) in an incubator where the temperature was kept at $25{ }^{\circ} \mathrm{C}$. Gaseous $\mathrm{HCHO}$ was generated by flowing helium through the paraformaldehyde container in a water bath kept at $35{ }^{\circ} \mathrm{C}$. Water vapor was generated by flowing helium through a water bubbler at $25{ }^{\circ} \mathrm{C}$. The feed gas composition is $140 \mathrm{ppm}$ of $\mathrm{HCHO}, 20 \% \mathrm{O}_{2}$ and $25 \% \mathrm{RH}$ balanced by helium. The total flow rate was $100 \mathrm{~mL} \mathrm{~min}{ }^{-1}$, corresponding to a gas hourly space velocity (GHSV) of $95000 \mathrm{~h}^{-1}$. The inlet and outlet gases were monitored by FTIR (Nicolet 380 ) equipped with 2 $\mathrm{m}$ gas cell and a DTGS detector; resolution: $0.5 \mathrm{~cm}^{-1}$; OPD velocity: $0.4747 \mathrm{~cm} \mathrm{~s}^{-1}$. The collect region was $4000-600 \mathrm{~cm}^{-1}$ and the number of scans per spectrum was 16 times. The representative FTIR spectra for $\mathrm{HCHO}$ oxidation reactions over $2 \mathrm{Na}-\mathrm{Pd} / \mathrm{TiO}_{2}-\mathrm{R}$ are shown in Figure $\mathrm{S} 1$ (Supporting Information). $\mathrm{HCHO}$ and $\mathrm{CO}_{2}$ were measured by the peaks located at 2897 ( $\mathrm{C}-\mathrm{H}$ vibration) and $2350 \mathrm{~cm}^{-1}(\mathrm{O}-\mathrm{C}-\mathrm{O}$ vibration), respectively. Since no other carbon-containing compounds except for $\mathrm{CO}_{2}$ were detected in the effluents for all tested catalysts, the $\mathrm{HCHO}$ and $\mathrm{CO}_{2}$ concentrations were quantified and calculated based on the peak area of $\mathrm{CO}_{2}$ at $2350 \mathrm{~cm}^{-1}$. Before the measurement, a $\mathrm{CO}_{2}$ standard curve was created using the different $\mathrm{CO}_{2}$ concentrations vs the peak areas at $2350 \mathrm{~cm}^{-1}$ and shown in Figure S2 (Supporting Information). The standard curve showed that the $\mathrm{CO}_{2}$ concentration below $500 \mathrm{ppm}$ is a linear function of the peak area at $2350 \mathrm{~cm}^{-1}$. 


\section{RESULTS AND DISCUSSION}

Activity Test. Figure 1 shows the $\mathrm{HCHO}$ conversion over $\mathrm{Pd} / \mathrm{TiO}_{2}$ and $2 \mathrm{Na}-\mathrm{Pd} / \mathrm{TiO}_{2}$ catalysts together with pure $\mathrm{TiO}_{2}$
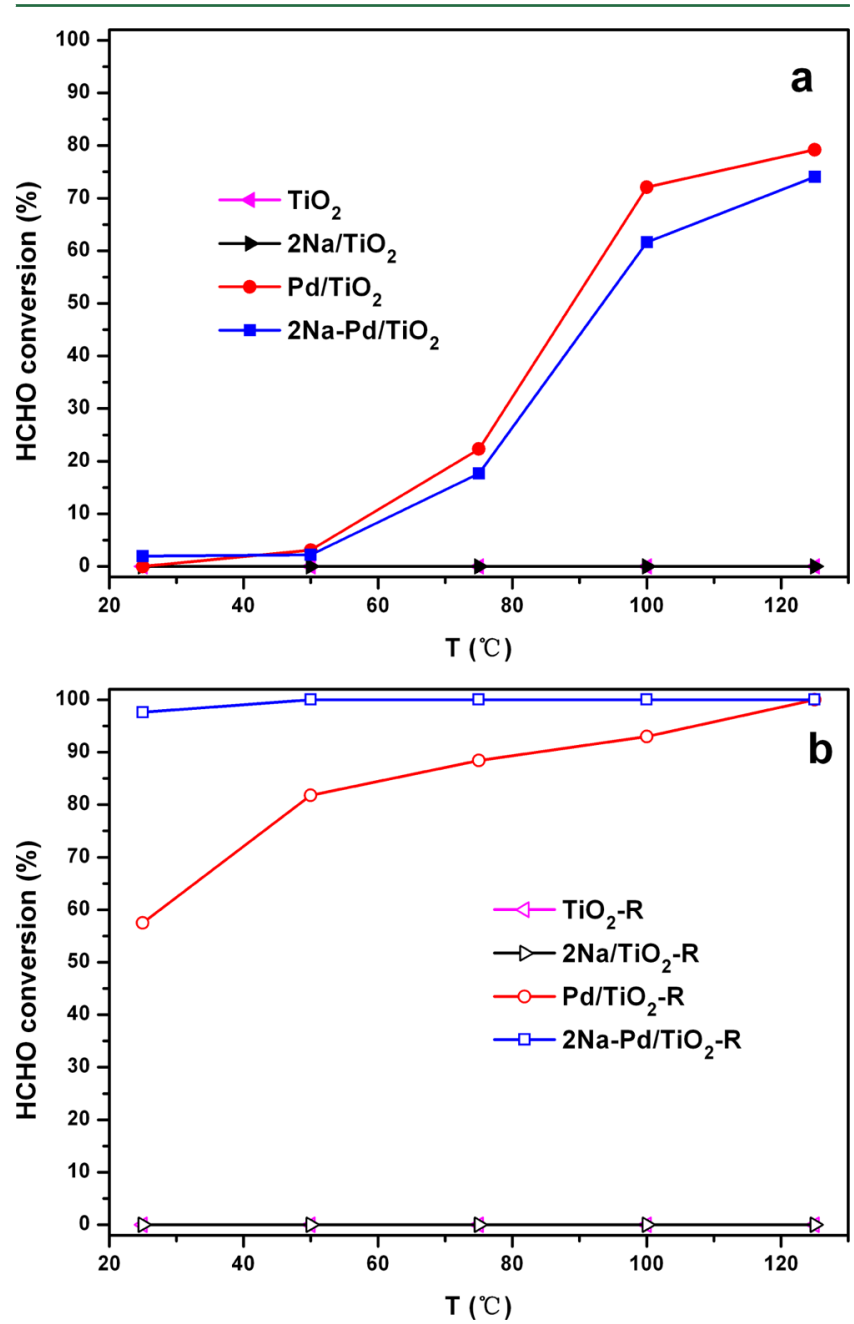

Figure 1. $\mathrm{HCHO}$ conversion over $\mathrm{TiO}_{2}, 2 \mathrm{Na} / \mathrm{TiO}_{2}, \mathrm{Pd} / \mathrm{TiO}_{2}$, and $2 \mathrm{Na}-\mathrm{Pd} / \mathrm{TiO}_{2}$ samples before (a) and after (b) reduction at different temperatures. Reaction conditions: $140 \mathrm{ppm}$ of $\mathrm{HCHO}, 20 \% \mathrm{O}_{2}, 25 \%$ $\mathrm{RH}, \mathrm{He}$ balance, GHSV $95000 \mathrm{~h}^{-1}$.

and $2 \mathrm{Na} / \mathrm{TiO}_{2}$ before (a) and after (b) pretreatment by $\mathrm{H}_{2}$. Pure $\mathrm{TiO}_{2}$ and $2 \mathrm{Na} / \mathrm{TiO}_{2}$ had no activity for $\mathrm{HCHO}$ oxidation at low temperatures $\left(25-125{ }^{\circ} \mathrm{C}\right)$ whether or not $\mathrm{H}_{2}$ reduction occurred. $2 \mathrm{Na}-\mathrm{Pd} / \mathrm{TiO}_{2}$ catalyst showed a similar activity to $\mathrm{Na}$-free catalyst before $\mathrm{H}_{2}$ pretreatment, but both of them were not active for $\mathrm{HCHO}$ oxidation at ambient temperatures (Figure 1a). In contrast, after $\mathrm{H}_{2}$ reduction, the activities of both $\mathrm{Pd} / \mathrm{TiO}_{2}$ and $\mathrm{Na}-\mathrm{Pd} / \mathrm{TiO}_{2}$ catalysts were greatly enhanced in the low temperature range (Figure $1 \mathrm{~b}$ ), indicating that metallic $\mathrm{Pd}$ species are active sites for the low temperature oxidation of HCHO. Remarkably, $\mathrm{Na}$ addition demonstrated a dramatic promotion effect on the reduced $\mathrm{Pd} / \mathrm{TiO}_{2}$. The $\mathrm{Pd} /$ $\mathrm{TiO}_{2}-\mathrm{R}$ catalyst only presented about $55 \% \mathrm{HCHO}$ conversion, while the $2 \mathrm{Na}-\mathrm{Pd} / \mathrm{TiO}_{2}-\mathrm{R}$ catalyst achieved almost $100 \%$ conversion of $140 \mathrm{ppm}$ of HCHO at a GHSV of $95000 \mathrm{~h}^{-1}$ at $25{ }^{\circ} \mathrm{C}$. The catalytic performance of the $2 \mathrm{Na}-\mathrm{Pd} / \mathrm{TiO}_{2}-\mathrm{R}$ catalyst was also checked by long isothermal tests at $25^{\circ} \mathrm{C}$. As shown in Figure 2, the sample exhibited excellent stability and efficiency with the same reaction conditions, and approximately $100 \% \mathrm{HCHO}$ conversion was maintained over a $30 \mathrm{~h}$ long test.

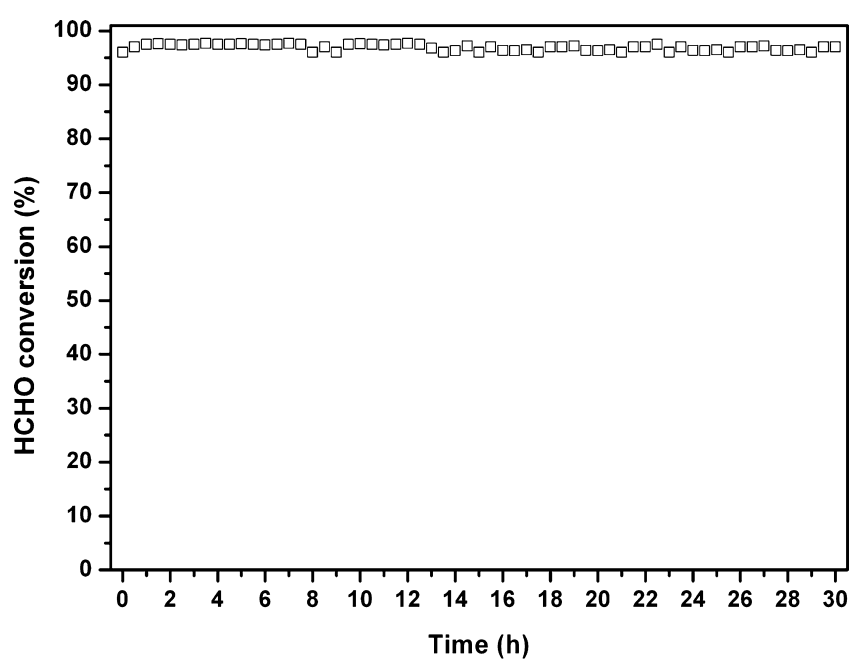

Figure 2. Stability test of $2 \mathrm{Na}-\mathrm{Pd} / \mathrm{TiO}_{2}-\mathrm{R}$. Reaction conditions: 25 ${ }^{\circ} \mathrm{C}, 140 \mathrm{ppm}$ of $\mathrm{HCHO}, 20 \% \mathrm{O}_{2}, 25 \% \mathrm{RH}$, He balance, GHSV 95000 $\mathrm{h}^{-1}$.

Structural Features of Catalysts. XRD patterns of Pd/ $\mathrm{TiO}_{2}$ and $2 \mathrm{Na}-\mathrm{Pd} / \mathrm{TiO}_{2}$ catalysts before and after $\mathrm{H}_{2}$ pretreatment together with $\mathrm{TiO}_{2}$ are shown in Figure 3. No

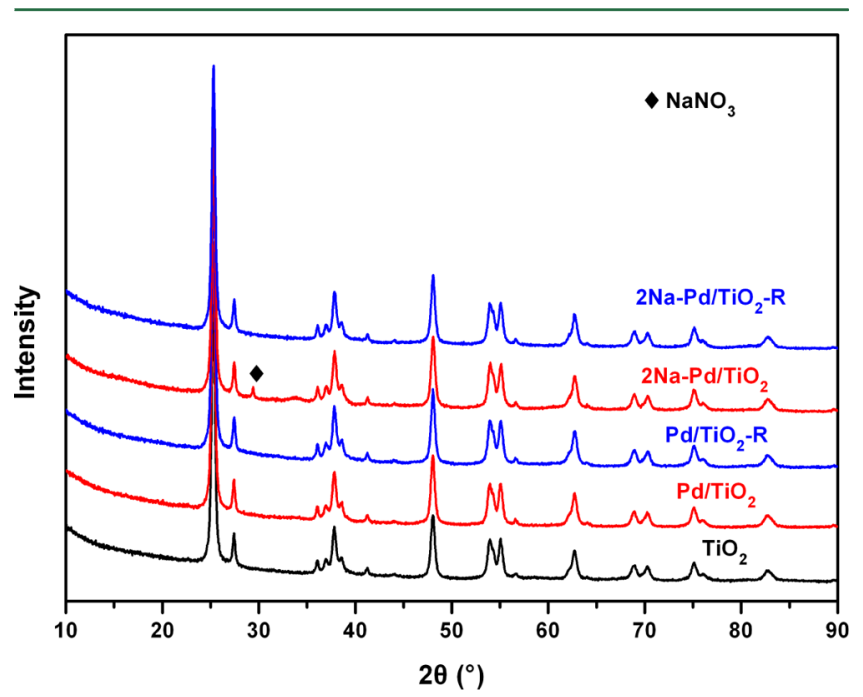

Figure 3. $\mathrm{XRD}$ patterns of $\mathrm{Pd} / \mathrm{TiO}_{2}, 2 \mathrm{Na}-\mathrm{Pd} / \mathrm{TiO}_{2}, \mathrm{Pd} / \mathrm{TiO}_{2}-\mathrm{R}$, and $2 \mathrm{Na}-\mathrm{Pd} / \mathrm{TiO}_{2}-\mathrm{R}$ together with $\mathrm{TiO}_{2}$ samples.

Pd species $\left(\mathrm{Pd}^{0}, \mathrm{PdO}\right)$ were observed in any samples, indicating that $\mathrm{Pd}$ species are highly dispersed on the $\mathrm{TiO}_{2}$ support. On the $2 \mathrm{Na}-\mathrm{Pd} / \mathrm{TiO}_{2}$ catalyst, a residual diffraction peak from undecomposed $\mathrm{NaNO}_{3}$ (PDF No. 00-001-0840) was observed at $2 \Theta=29.4^{\circ}$, and it disappeared after $\mathrm{H}_{2}$ treatment at $350{ }^{\circ} \mathrm{C}$, implying that the residual $\mathrm{NaNO}_{3}$ was reduced. ${ }^{31}$

The specific surface area $\left(S_{\mathrm{BET}}\right)$, average pore size $(d)$, and total pore volume $(V)$ of $\mathrm{Pd} / \mathrm{TiO}_{2}$ and $2 \mathrm{Na}-\mathrm{Pd} / \mathrm{TiO}_{2}$ catalysts before and after $\mathrm{H}_{2}$ pretreatment were next measured, the results are listed in Table 1 , and the plots of pore size distribution are shown in Figure S3 (Supporting Information). The $\mathrm{Pd} / \mathrm{TiO}_{2}$ catalyst showed a similar $S_{\mathrm{BET}}, V$, and average pore size $(d)$ to bare $\mathrm{TiO}_{2}$ whether or not $\mathrm{H}_{2}$ reduction had 
taken place. The $\mathrm{Na}$ addition to $\mathrm{Pd} / \mathrm{TiO}_{2}$ catalyst decreased the $S_{\mathrm{BET}}$ and $V$ but increased the average pore size $(d)$, probably due to the deposition of $\mathrm{NaNO}_{3}$ inside the small pores of $\mathrm{TiO}_{2}$. During the $\mathrm{H}_{2}$ reduction at $350{ }^{\circ} \mathrm{C}$, some $\mathrm{Na}$ species possibly migrated out of the small pores, increasing the $S_{\mathrm{BET}}$ and $V$ and decreasing the average pore size $(d)$ of the $2 \mathrm{Na}-\mathrm{Pd} / \mathrm{TiO}_{2}-\mathrm{R}$ sample.

Pd Dispersion and Sizes on Catalysts. Pd dispersion was determined by $\mathrm{CO}$ chemisorption, and Pd particle sizes were calculated based on Pd dispersion degree. The results of Pd dispersion and particle size are shown in Table 1 . Without $\mathrm{Na}$ addition, the $\mathrm{Pd}$ dispersion was only $9.8 \%$ and the $\mathrm{Pd}$ particle size was around $11.4 \mathrm{~nm}$ on the $\mathrm{Pd} / \mathrm{TiO}_{2}-\mathrm{R}$ catalyst. $\mathrm{Na}$ addition to $\mathrm{Pd} / \mathrm{TiO}_{2}$ remarkably increased the $\mathrm{Pd}$ dispersion to $32.9 \%$, and the Pd particle size sharply dropped to $3.4 \mathrm{~nm}$. Clearly, $\mathrm{Na}$ addition induces a more dispersed $\mathrm{Pd}$ species on $2 \mathrm{Na}-\mathrm{Pd} / \mathrm{TiO}_{2}-\mathrm{R}$ catalyst that exposes more $\mathrm{Pd}$ sites for $\mathrm{HCHO}$ oxidation, therefore significantly promoting the activity of the $\mathrm{Pd} / \mathrm{TiO}_{2}$ catalyst.

Reducibility of Catalysts. $\mathrm{H}_{2}$-TPR was conducted to study the reducibility of the catalysts, and the TPR profiles of $\mathrm{Pd}$ / $\mathrm{TiO}_{2}, 2 \mathrm{Na}-\mathrm{Pd} / \mathrm{TiO}_{2}, 2 \mathrm{Na} / \mathrm{TiO}_{2}$, and pure $\mathrm{TiO}_{2}$ are shown in Figure 4. Pure $\mathrm{TiO}_{2}$ exhibited no $\mathrm{H}_{2}$ consumption peak in the

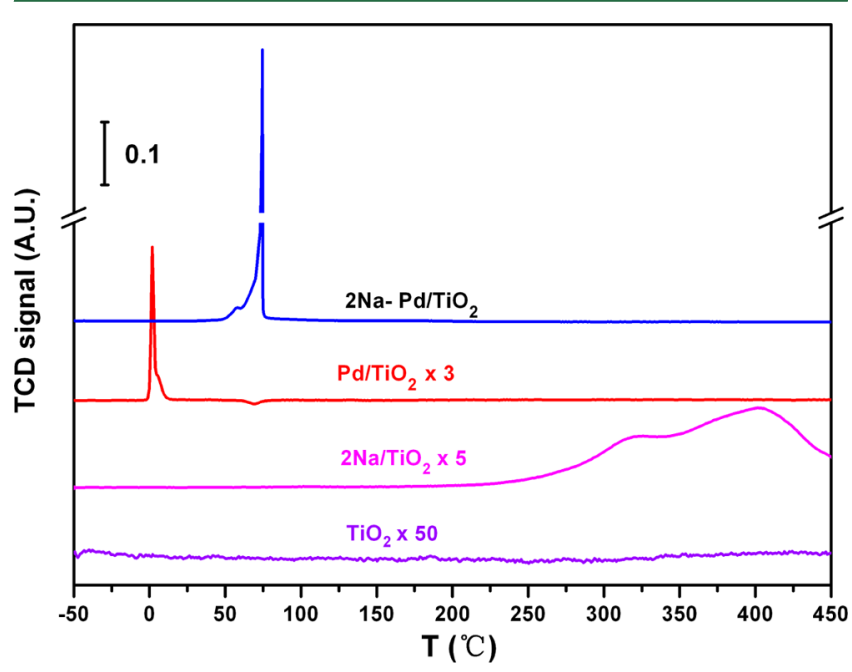

Figure 4. $\mathrm{H}_{2}$ - TPR profiles of $\mathrm{TiO}_{2}, 2 \mathrm{Na} / \mathrm{TiO}_{2}, \mathrm{Pd} / \mathrm{TiO}_{2}$, and $2 \mathrm{Na}-$ $\mathrm{Pd} / \mathrm{TiO}_{2}$ samples.

-50 to $+450{ }^{\circ} \mathrm{C}$ range since $\mathrm{TiO}_{2}$ reduction normally occurs at $\mathrm{T}>600{ }^{\circ} \mathrm{C} .{ }^{32} \mathrm{The} 2 \mathrm{Na} / \mathrm{TiO}_{2}$ sample presented a broad peak at 200-450 ${ }^{\circ} \mathrm{C}$, which is assigned to the reduction of $\mathrm{Na}$ species. ${ }^{31}$ After $\mathrm{Pd}$ was loaded, $\mathrm{Pd} / \mathrm{TiO}_{2}$ showed a sharp $\mathrm{PdO}$ reduction peak at around $0{ }^{\circ} \mathrm{C} .{ }^{33}$ With the further addition of $\mathrm{Na}$, the PdO reduction peak shifted to higher temperature at about $58{ }^{\circ} \mathrm{C}$, while the reduction peak of $\mathrm{Na}$ species shifted toward low temperature, at about $75{ }^{\circ} \mathrm{C}$. The above results indicate a strong interaction between the $\mathrm{Na}$ species and $\mathrm{Pd}$ species, with the $\mathrm{Na}$ species stabilizing the $\mathrm{Pd}$ species and the existence of $\mathrm{Pd}$ species facilitating the reduction of the $\mathrm{Na}$ species. $^{31,34}$

XPS Analysis. XPS measurements were next carried out to identify the states of $\mathrm{Pd}, \mathrm{Ti} \mathrm{O}$ and $\mathrm{Na}$ elements on the catalyst surface. The XPS spectra are shown in Figure 5; the binding energies and the percentages of XPS peaks calculated are summarized in Table 2. As shown in Figure 5a, the fresh $\mathrm{Pd} /$ $\mathrm{TiO}_{2}$ and $2 \mathrm{Na}-\mathrm{Pd} / \mathrm{TiO}_{2}$ only presented one $\mathrm{Pd} 3 \mathrm{~d}_{5 / 2}$ peak centered at $336.4 \mathrm{eV}$, indicating that the $\mathrm{Pd}$ species are all in the oxide state. ${ }^{35}$ After the catalysts were reduced at $350{ }^{\circ} \mathrm{C}, \mathrm{Pd} /$ $\mathrm{TiO}_{2}-\mathrm{R}$ displayed two $\mathrm{Pd} 3 \mathrm{~d}_{5 / 2}$ peaks at 336.4 and $335.1 \mathrm{eV}$ characteristic of $\mathrm{Pd}$ oxide and metallic $\mathrm{Pd}$. The calculation results (Table 2) showed that about $66 \%$ of Pd species were in the metallic $\mathrm{Pd}$ state. In contrast, with $\mathrm{Na}$ addition, the $2 \mathrm{Na}-$ $\mathrm{Pd} / \mathrm{TiO}_{2}-\mathrm{R}$ catalyst presented a third $\mathrm{Pd} 3 \mathrm{~d}_{5 / 2}$ peak at the low binding energy of $334.0 \mathrm{eV}$ alongside the peaks at 336.4 and $335.1 \mathrm{eV}$, indicating that the doped $\mathrm{Na}$, as an electron donor, leads to the formation of a negatively charged Pd species by its strong interaction with metallic $\mathrm{Pd}{ }^{36,37}$ This formed negatively charged Pd species could enhance $\mathrm{O}_{2}$ adsorption by the donation of electrons from Pd metal to the antibonding $\pi^{*}$ orbital of $\mathrm{O}_{2} \cdot{ }^{27,38} \mathrm{In}$ addition, it was dominant $(65.1 \%)$ on the $2 \mathrm{Na}-\mathrm{Pd} / \mathrm{TiO}_{2}-\mathrm{R}$ catalyst surface, therefore playing the key role in the ambient $\mathrm{HCHO}$ oxidation.

Figure $5 \mathrm{~b}$ shows the $\mathrm{Ti} 2 \mathrm{p}$ peaks of the series of catalysts. The peak at $458.8 \mathrm{eV}$ over the $\mathrm{Pd} / \mathrm{TiO}_{2}$ catalyst was ascribed to $\mathrm{Ti}^{4+}$ of $\mathrm{TiO}_{2}{ }^{27}$ A slight negative shift of $0.3 \mathrm{eV}$ over $\mathrm{Pd} / \mathrm{TiO}_{2}-\mathrm{R}$ should be related to the formation of $\mathrm{TiO}_{2-x}$ species during the reduction process. ${ }^{39}$ In comparison, after $\mathrm{Na}$ addition, the $\mathrm{Ti} 2 \mathrm{p}$ peaks shifted to $458.3 \mathrm{eV}$ over $2 \mathrm{Na}-\mathrm{Pd} / \mathrm{TiO}_{2}$ and $2 \mathrm{Na} / \mathrm{TiO}_{2}$ and then shifted to $458.0 \mathrm{eV}$ over $2 \mathrm{Na}-\mathrm{Pd} / \mathrm{TiO}_{2}-\mathrm{R}$ and $2 \mathrm{Na} /$ $\mathrm{TiO}_{2}-\mathrm{R}$ samples. The above findings show that the doped $\mathrm{Na}$ species may interact with the support and improve the reduction of $\mathrm{TiO}_{2}{ }^{40}$ This finding is consistent with the observations of Onishi, et al., ${ }^{41}$ who reported that $\mathrm{Na}$ deposited on $\mathrm{TiO}_{2}$ (110) strongly interacted with surface oxygen atoms thereby causing the charge transfer to the substrate and the reduction of $\mathrm{Ti}^{4+}$ to $\mathrm{Ti}^{3+}$.

Figure 5c shows the $\mathrm{O}$ 1s XPS spectra of the catalysts. Two kinds of $\mathrm{O}$ species were observed in all samples. The main peak at the binding energy range of 529.2-529.7 eV was assigned to the lattice oxygen of bulk $\mathrm{TiO}_{2}\left(\mathrm{O}_{\mathrm{I}}\right)$, and the small shoulder peak at the binding energy range $530.8-531.5 \mathrm{eV}$ was ascribed to $\mathrm{Ti}-\mathrm{OH} .{ }^{39}$ As can be seen in Table 2 , the percentage of Ti$\mathrm{OH}$ species $\left(\mathrm{O}_{\mathrm{II}}\right)$ was about $9.0 \%$ over the $\mathrm{Pd} / \mathrm{TiO}_{2}-\mathrm{R}$ samples, while the percentage of $\mathrm{Ti}-\mathrm{OH}$ species $\left(\mathrm{O}_{\mathrm{II}}\right)$ increased to $15.7 \%$ over the $2 \mathrm{Na}-\mathrm{Pd} / \mathrm{TiO}_{2}-\mathrm{R}$ catalyst, demonstrating that $\mathrm{Na}$ addition increases the concentration of surface $\mathrm{OH}$ groups. ${ }^{42}$ We have reported that the reaction between surface $\mathrm{OH}$ and formate species to give final products is a facile reaction pathway for ambient $\mathrm{HCHO}$ oxidation. ${ }^{26}$ Therefore, in this work, the enhancement of surface $\mathrm{OH}$ concentration with $\mathrm{Na}$ addition also partially accounts for the activity improvement of $2 \mathrm{Na}-\mathrm{Pd} / \mathrm{TiO}_{2}-\mathrm{R}$.

The XPS data of $\mathrm{Na} 1 \mathrm{~s}$ are shown in Figure 5d. Peaks at $1071.3 \mathrm{eV}$ over $2 \mathrm{Na} / \mathrm{TiO}_{2}$ and $2 \mathrm{Na}-\mathrm{Pd} / \mathrm{TiO}_{2}$ catalysts were ascribed to $\mathrm{Na}^{+}$in the form of $\mathrm{NaNO}_{3}{ }^{43}$ further confirming the successful loading of $\mathrm{Na}$ species on $\mathrm{TiO}_{2}$. After the catalysts were reduced, the $\mathrm{Na}$ 1s peaks were shifted to lower band energy, which could be attributed to the partial reduction of surface $\mathrm{Na}^{+}$or the incorporation of $\mathrm{Na}^{+}$into $\mathrm{TiO}_{2}{ }^{44}$

$\mathrm{O}_{2}$-TPD. $\mathrm{O}_{2}$-TPD experiments were next performed to investigate the $\mathrm{O}_{2}$ activation over the $\mathrm{Pd} / \mathrm{TiO}_{2}-\mathrm{R}$ and $2 \mathrm{Na}-\mathrm{Pd} /$ $\mathrm{TiO}_{2}-\mathrm{R}$ catalysts, and the profiles are shown in Figure 6. There was only one broad $\mathrm{O}_{2}$ desorption peak presented on both $\mathrm{Pd} /$ $\mathrm{TiO}_{2}-\mathrm{R}$ and $2 \mathrm{Na}-\mathrm{Pd} / \mathrm{TiO}_{2}-\mathrm{R}$ samples in the temperature range of 25 to $400{ }^{\circ} \mathrm{C}$. For the $\mathrm{Pd} / \mathrm{TiO}_{2}-\mathrm{R}$ catalyst, the $\mathrm{O}_{2}$ desorption occurred at $142{ }^{\circ} \mathrm{C}$ and the peak was centered at $221{ }^{\circ} \mathrm{C}$. After $\mathrm{Na}$ addition, the $\mathrm{O}_{2}$ desorption peak shifted to the low temperature range, starting at $89^{\circ} \mathrm{C}$ and centered at $180{ }^{\circ} \mathrm{C}$, indicating that $\mathrm{Na}$ species addition enhanced the mobility and 

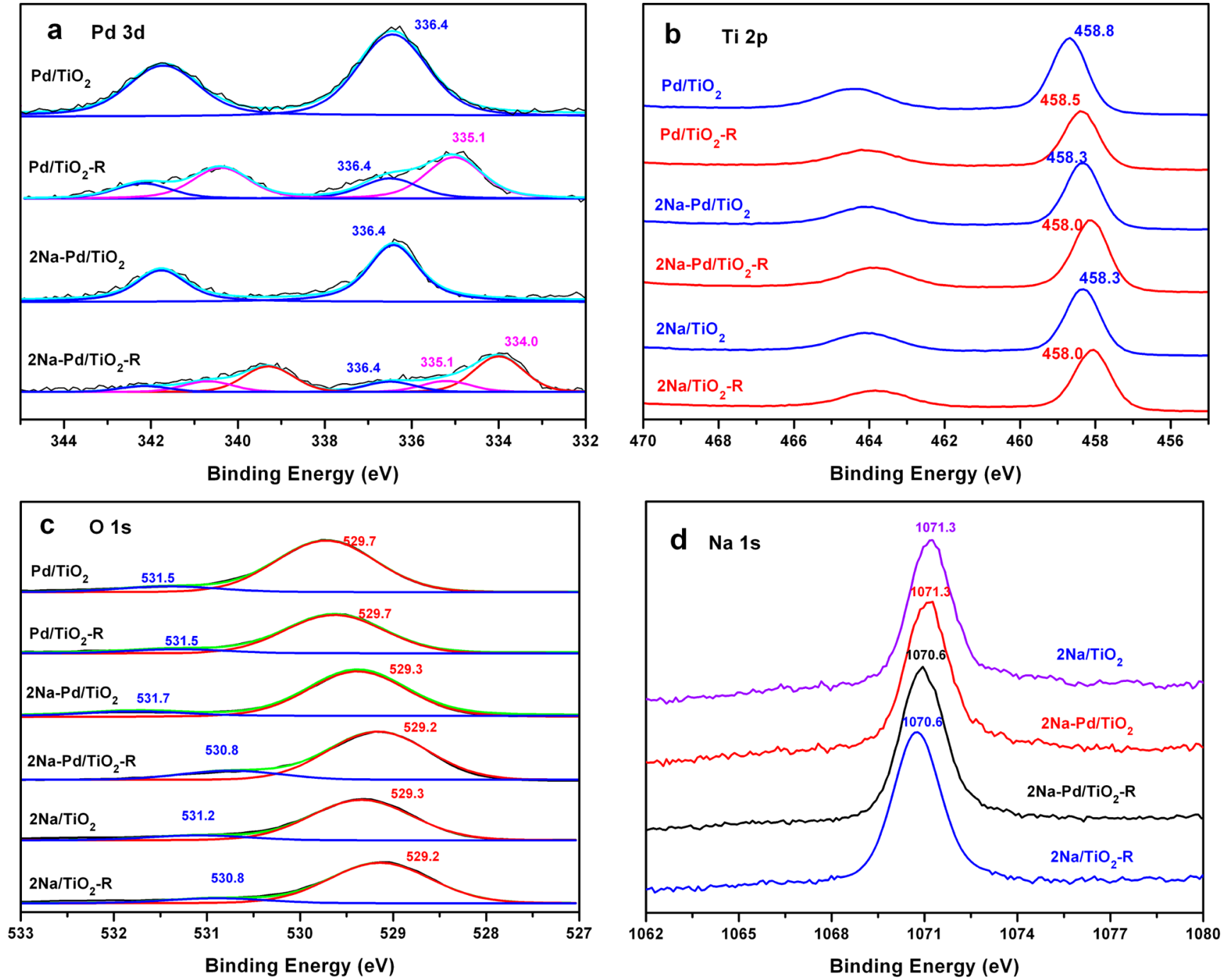

Figure 5. XPS spectra of $\mathrm{Pd} / \mathrm{TiO}_{2}, 2 \mathrm{Na}-\mathrm{Pd} / \mathrm{TiO}_{2}, \mathrm{Pd} / \mathrm{TiO}_{2}-\mathrm{R}$, and $2 \mathrm{Na}-\mathrm{Pd} / \mathrm{TiO}_{2}-\mathrm{R}$ together with $2 \mathrm{Na} / \mathrm{TiO}$ and $2 \mathrm{Na} / \mathrm{TiO}$ - $\mathrm{R}$ samples: (a) $\mathrm{Pd} 3 \mathrm{~d}$, (b) Ti $2 \mathrm{p},(\mathrm{c}) \mathrm{O} 1 \mathrm{~s}$, and (d) $\mathrm{Na} 1 \mathrm{~s}$.

Table 2. XPS Data of $\mathrm{Pd} / \mathrm{TiO}_{2}, 2 \mathrm{Na}-\mathrm{Pd} / \mathrm{TiO}_{2}, \mathrm{Pd} / \mathrm{TiO}_{2}-\mathrm{R}$ and $2 \mathrm{Na}-\mathrm{Pd} / \mathrm{TiO}_{2}-\mathrm{R}$ together with $2 \mathrm{Na} / \mathrm{TiO}_{2}$ and $2 \mathrm{Na} /$ $\mathrm{TiO}_{2}$-R Samples

\begin{tabular}{|c|c|c|c|c|c|c|}
\hline & $\mathrm{Pd} 3 \mathrm{~d}$ & & O $1 \mathrm{~s}$ & & Ti $2 p$ & $\mathrm{Na} 1 \mathrm{~s}$ \\
\hline samples & $\begin{array}{l}\text { B.E. } \\
(\mathrm{eV})\end{array}$ & $\begin{array}{c}\text { ratio } \\
(\%)\end{array}$ & $\begin{array}{l}\text { B.E. } \\
(\mathrm{eV})\end{array}$ & $\begin{array}{c}\text { ratio } \\
(\%)\end{array}$ & $\begin{array}{l}\text { B.E. } \\
(\mathrm{eV})\end{array}$ & $\begin{array}{l}\text { B.E. } \\
(\mathrm{eV})\end{array}$ \\
\hline $\mathrm{Pd} / \mathrm{TiO}_{2}$ & 336.4 & & 529.7 & 91.1 & 458.8 & \\
\hline & & & 531.4 & 8.9 & & \\
\hline $\mathrm{Pd} / \mathrm{TiO}_{2}-\mathrm{R}$ & 335.1 & 66.0 & 529.1 & 90.5 & 458.5 & \\
\hline & 336.4 & 34.0 & 531.4 & 9.5 & & \\
\hline $2 \mathrm{Na}-\mathrm{Pd} / \mathrm{TiO}_{2}$ & 336.4 & & 529.3 & 91.1 & 458.3 & 1071.3 \\
\hline & & & 531.8 & 8.9 & & \\
\hline $2 \mathrm{Na}-\mathrm{Pd} /$ & 334.0 & 65.1 & 529.2 & 84.3 & 458.0 & 1070.6 \\
\hline & 335.1 & 19.3 & 530.8 & 15.7 & & \\
\hline & 336.4 & 15.6 & & & & \\
\hline $2 \mathrm{Na} / \mathrm{TiO}_{2}$ & & & 529.3 & 91.0 & 458.3 & 1071.3 \\
\hline & & & 531.2 & 9.0 & & \\
\hline $2 \mathrm{Na} / \mathrm{TiO}_{2}-\mathrm{R}$ & & & 529.2 & 89.1 & 458.0 & 1070.6 \\
\hline & & & 530.8 & 10.9 & & \\
\hline
\end{tabular}

activation of the chemisorbed oxygen over the $2 \mathrm{Na}-\mathrm{Pd} / \mathrm{TiO}_{2}-$ $\mathrm{R}$ catalyst. The enhanced activation of chemisorbed oxygen by

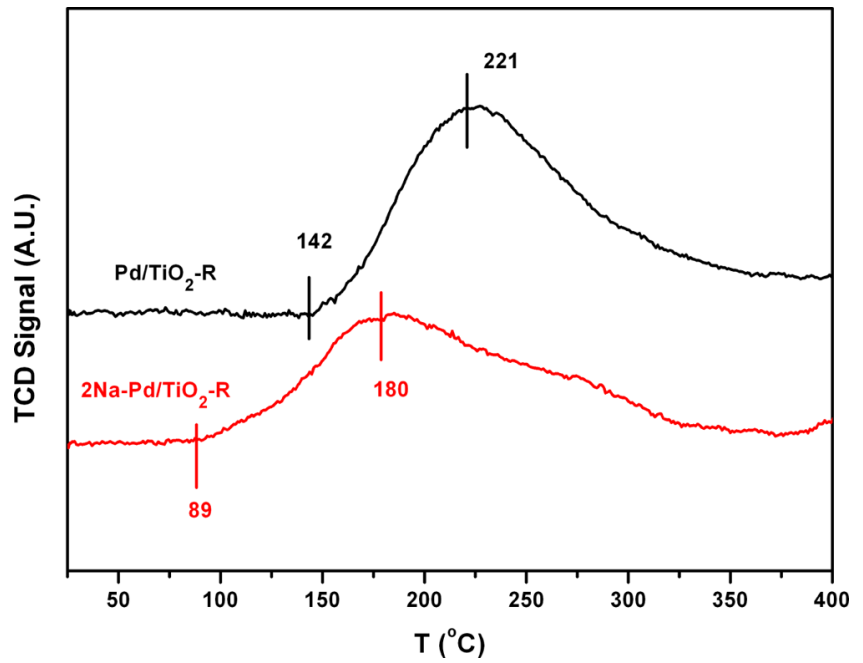

Figure 6. $\mathrm{O}_{2}-\mathrm{TPD}$ profiles of $\mathrm{Pd} / \mathrm{TiO}_{2}-\mathrm{R}$ and $2 \mathrm{Na}-\mathrm{Pd} / \mathrm{TiO}_{2}-\mathrm{R}$ samples.

$\mathrm{Na}$ addition should also contribute to the excellent activity of $2 \mathrm{Na}-\mathrm{Pd} / \mathrm{TiO}_{2}-\mathrm{R}$. 
In summary, this work demonstrates that the Na addition has a dramatic promotion effect on this Pd-based catalyst for ambient $\mathrm{HCHO}$ oxidation. As shown above, $\mathrm{Na}$ addition to $\mathrm{Pd} / \mathrm{TiO}_{2}$ led to the formation of a well-dispersed $\mathrm{Pd}$ species that facilitated the activation of surface $\mathrm{OH}$ groups and chemisorbed oxygen and thus significantly increased the catalytic activity of $\mathrm{Pd} / \mathrm{TiO}_{2}$ catalyst for ambient $\mathrm{HCHO}$ destruction. This work further confirmed the alkali ion promotion effect on the catalytic activity of noble metal based catalysts.

\section{ASSOCIATED CONTENT}

\section{S Supporting Information}

Representative FTIR spectra for $\mathrm{HCHO}$ oxidation reactions, the standard curve of $\mathrm{CO}_{2}$ concentration, and plots of pore size distribution. This material is available free of charge via the Internet at http://pubs.acs.org/.

\section{AUTHOR INFORMATION}

\section{Corresponding Author}

*Phone: 86-10-62849123. Fax: 86-10-62849123. E-mail: honghe@rcees.ac.cn.

\section{Author Contributions}

${ }^{\dagger}$ These authors contributed equally to this work.

\section{Notes}

The authors declare no competing financial interest.

\section{ACKNOWLEDGMENTS}

This work was financially supported by the National Natural Science Foundation of China (21077117) and the Program of the Ministry of Science and Technology of China (2012AA062702 and 2010AA064905).

\section{REFERENCES}

(1) Yu, C.; Crump, D. A review of the emission of VOCs from polymeric materials used in buildings. Build. Environ. 1998, 33 (6), 357-374.

(2) Maddalena, R.; Russell, M.; Sullivan, D. P.; Apte, M. G. Formaldehyde and Other Volatile Organic Chemical Emissions in Four FEMA Temporary Housing Units. Environ. Sci. Technol. 2009, 43 (15), 5626-5632.

(3) Formaldehyde: Assessing the risk. Environ. Sci. Technol. 1984, 18, (7), 216A-221A.

(4) Rong, H.; Liu, Z.; Wu, Q.; Pan, D.; Zheng, J. Formaldehyde removal by Rayon-based activated carbon fibers modified by Paminobenzoic acid. Cellulose 2009, 17 (1), 205-214.

(5) Moreno-Pirajan, J. C.; Tirano, J.; Salamanca, B.; Giraldo, L. Activated carbon modified with copper for adsorption of propanethiol. Int. J. Mol. Sci. 2010, 11 (3), 927-942.

(6) Noguchi, T.; Fujishima, A.; Sawunyama, P.; Hashimoto, K. Photocatalytic Degradation of Gaseous Formaldehyde Using $\mathrm{TiO}_{2}$ Film. Environ. Sci. Technol. 1998, 32 (23), 3831-3833.

(7) Shiraishi, F.; Ohkubo, D.; Toyoda, K.; Yamaguchi, S. Decomposition of gaseous formaldehyde in a photocatalytic reactor with a parallel array of light sources. Chem. Eng. J. 2005, 114 (1-3), 153-159.

(8) Chang, M. B.; Lee, C. C. Destruction of formaldehyde with dielectric barrier discharge plasmas. Environ. Sci. Technol. 1995, 29 (1), 181-186.

(9) Quiroz Torres, J.; Royer, S.; Bellat, J. P.; Giraudon, J. M.; Lamonier, J. F. Formaldehyde: catalytic oxidation as a promising soft way of elimination. ChemSusChem 2013, 6 (4), 578-592.

(10) Pei, J.; Zhang, J. S. Critical review of catalytic oxidization and chemisorption methods for indoor formaldehyde removal. HVACR Res. 2011, 17 (4), 476-503.
(11) Bai, B. Y.; Arandiyan, H.; Li, J. H. Comparison of the performance for oxidation of formaldehyde on nano- $\mathrm{Co}_{3} \mathrm{O}_{4}, 2 \mathrm{D}$ $\mathrm{Co}_{3} \mathrm{O}_{4}$, and 3D- $\mathrm{Co}_{3} \mathrm{O}_{4}$ catalysts. Appl. Catal. B 2013, 142, 677-683.

(12) Ma, L.; Wang, D.; Li, J.; Bai, B.; Fu, L.; Li, Y. Ag/CeO nanospheres: Efficient catalysts for formaldehyde oxidation. Appl. Catal., B 2014, 148-149, 36-43.

(13) Qu, Z.; Shen, S.; Chen, D.; Wang, Y. Highly active Ag/SBA-15 catalyst using post-grafting method for formaldehyde oxidation. J. Mol. Catal. A: Chem. 2012, 356, 171-177.

(14) Imamura, S.; Uchihori, D.; Utani, K.; Ito, T. Oxidative Decomposition of Formaldehyde on Silver-Cerium Composite Oxide Catalyst. Catal. Lett. 1994, 24 (3-4), 377-384.

(15) Wen, Y.; Tang, X.; Li, J.; Hao, J.; Wei, L.; Tang, X. Impact of synthesis method on catalytic performance of $\mathrm{MnO}_{x}-\mathrm{SnO}_{2}$ for controlling formaldehyde emission. Catal. Commun. 2009, 10 (8), 1157-1160.

(16) Chen, T.; Dou, H.; Li, X.; Tang, X.; Li, J.; Hao, J. Tunnel structure effect of manganese oxides in complete oxidation of formaldehyde. Micropor. Mesopor. Mater. 2009, 122 (1-3), 270-274.

(17) Tang, X.; Li, Y.; Huang, X.; Xu, Y.; Zhu, H.; Wang, J.; Shen, W. $\mathrm{MnO}_{x}-\mathrm{CeO}_{2}$ mixed oxide catalysts for complete oxidation of formaldehyde: Effect of preparation method and calcination temperature. Appl. Catal., B 2006, 62 (3-4), 265-273.

(18) Xu, Q. J.; Zhang, Y. P.; Mo, J. H.; Li, X. X. Indoor Formaldehyde Removal by Thermal Catalyst: Kinetic Characteristics, Key Parameters, and Temperature Influence. Environ. Sci. Technol. 2011, 45 (13), 5754-5760.

(19) Sekine, Y. Oxidative decomposition of formaldehyde by metal oxides at room temperature. Atmos. Environ. 2002, 36 (35), 55435547.

(20) Zhang, C.; He, H.; Tanaka, K.-i. Perfect catalytic oxidation of formaldehyde over a $\mathrm{Pt} / \mathrm{TiO}_{2}$ catalyst at room temperature. Catal. Commun. 2005, 6 (3), 211-214.

(21) Zhang, C.; He, H.; Tanaka, K.-i. Catalytic performance and mechanism of a Pt $/ \mathrm{TiO}_{2}$ catalyst for the oxidation of formaldehyde at room temperature. Appl. Catal., B 2006, 65 (1-2), 37-43.

(22) Zhang, C.; He, H. A comparative study of $\mathrm{TiO}_{2}$ supported noble metal catalysts for the oxidation of formaldehyde at room temperature. Catal. Today 2007, 126 (3-4), 345-350.

(23) Kim, S. S.; Park, K. H.; Hong, S. C. A study on HCHO oxidation characteristics at room temperature using a $\mathrm{Pt} / \mathrm{TiO}_{2}$ catalyst. Appl. Catal., A 2011, 398 (1-2), 96-103.

(24) Imamura, S.; Uematsu, Y.; Utani, K.; Ito, T. Combustion of formaldehyde on ruthenium/cerium (IV) oxide catalyst. Ind. Eng. Chem. Res. 1991, 30 (1), 18-21.

(25) Álvarez-Galván, M. C.; de la Peña O’Shea, V. A.; Fierro, J. L. G.; Arias, P. L. Alumina-supported manganese- and manganese-palladium oxide catalysts for VOCs combustion. Catal. Commun. 2003, 4 (5), 223-228.

(26) Zhang, C.; Liu, F.; Zhai, Y.; Ariga, H.; Yi, N.; Liu, Y.; Asakura, K.; Flytzani-Stephanopoulos, M.; He, H. Alkali-metal-promoted Pt/ $\mathrm{TiO}_{2}$ opens a more efficient pathway to formaldehyde oxidation at ambient temperatures. Angew. Chem., Int. Ed. 2012, 51 (38), 96289632.

(27) Huang, H.; Leung, D. Y. C. Complete oxidation of formaldehyde at room temperature using $\mathrm{TiO}_{2}$-supported metallic Pd nanoparticles. ACS Catal. 2011, 1 (4), 348-354.

(28) Li, H.-F.; Zhang, N.; Chen, P.; Luo, M.-F.; Lu, J.-Q. High surface area $\mathrm{Au} / \mathrm{CeO}_{2}$ catalysts for low temperature formaldehyde oxidation. Appl. Catal., B 2011, 110, 279-285.

(29) Fox, E. B.; Velu, S.; Engelhard, M. H.; Chin, Y.-H.; Miller, J. T.; Kropf, J.; Song, C. Characterization of $\mathrm{CeO}_{2}$-supported $\mathrm{Cu}-\mathrm{Pd}$ bimetallic catalyst for the oxygen-assisted water-gas shift reaction. J. Catal. 2008, 260 (2), 358-370.

(30) Anderson, J. R. Structure of Metallic Catalysts; Academic Press: London, 1975; Vol. 379.

(31) Zhu, X.; Shen, M.; Lobban, L. L.; Mallinson, R. G. Structural effects of $\mathrm{Na}$ promotion for high water gas shift activity on $\mathrm{Pt}-\mathrm{Na}$ / $\mathrm{TiO}_{2}$. J. Catal. 2011, 278 (1), 123-132. 
(32) de Resende, N. S.; Eon, J.-G.; Schmal, M. Pt/ $\mathrm{TiO}_{2}-\gamma-\mathrm{Al}_{2} \mathrm{O}_{3}$ catalyst: I. Dispersion of platinum on alumina-grafted titanium oxide. $J$. Catal. 1999, 183 (1), 6-13.

(33) $\mathrm{Zhu}, \mathrm{H} . \mathrm{Pd} / \mathrm{CeO}_{2}-\mathrm{TiO}_{2}$ catalyst for $\mathrm{CO}$ oxidation at low temperature: a TPR study with $\mathrm{H}_{2}$ and $\mathrm{CO}$ as reducing agents. J. Catal. 2004, 225 (2), 267-277.

(34) Gusovius, A. F.; Watling, T. C.; Prins, R. Ca promoted $\mathrm{Pd} / \mathrm{SiO}_{2}$ catalysts for the synthesis of methanol from $\mathrm{CO}$ : the location of the promoter. Appl. Catal., A 1999, 188 (1-2), 187-199.

(35) Otto, K.; Haack, L. P.; deVries, J. E. Identification of two types of oxidized palladium on $\gamma$-alumina by X-ray photoelectron spectroscopy. Appl. Catal., B 1992, 1 (1), 1-12.

(36) Liotta, L. F.; Deganello, G.; Delichere, P.; Leclercq, C.; Martin, G. A. Localization of alkali metal ions in sodium-promoted palladium catalysts as studied by low energy ion scattering and transmission electron microscopy. J. Catal. 1996, 164 (2), 334-340.

(37) Liotta, L. F.; Martin, G. A.; Deganello, G. The influence of alkali metal ions in the chemisorption of $\mathrm{CO}$ and $\mathrm{CO}_{2}$ on supported palladium catalysts: A fourier transform infrared spectroscopic study. $J$. Catal. 1996, 164 (2), 322-333.

(38) Vayenas, C. G.; Bebelis, S; Pliangos, C.; Brosda, S.; Tsiplakides, D. Electrochemical Activation of Catalysis: Promotion, Electrochemical Promotion, And Metal-Support Interactions; Kluwer Academic Publishers/Plenum Press: New York, 2001.

(39) Nie, L.; Yu, J.; Li, X.; Cheng, B.; Liu, G.; Jaroniec, M. Enhanced performance of $\mathrm{NaOH}$-modified $\mathrm{Pt} / \mathrm{TiO}_{2}$ toward room temperature selective oxidation of formaldehyde. Environ. Sci. Technol. 2013, 47 (6), $2777-2783$

(40) Panagiotopoulou, P.; Kondarides, D. I. Effects of alkali promotion of $\mathrm{TiO}_{2}$ on the chemisorptive properties and water-gas shift activity of supported noble metal catalysts. J. Catal. 2009, 267 (1), 57-66.

(41) Onishi, H.; Aruga, T.; Egawa, C.; Iwasawa, Y. Modification of surface electronic-structure on $\mathrm{TiO}_{2}(110)$ and $\mathrm{TiO}_{2}$ (441) by Na deposition. Surf. Sci. 1988, 199 (1-2), 54-66.

(42) Brookes, I.; Muryn, C.; Thornton, G. Imaging water dissociation on $\mathrm{TiO}_{2}$ (110). Phys. Rev. Lett. 2001, 87 (26), 266103(1-4).

(43) Wagner, C. D. Chemical shifts of Auger lines, and the Auger parameter. Faraday Discuss. Chem. Soc. 1975, 60, 291-300.

(44) Yoshida, A.; Shen, W.; Eda, T.; Watanabe, R.; Ito, T.; Naito, S. NOx storage/reduction over alkali-metal-nitrate impregnated titanate nanobelt catalysts and investigation of alkali metal cation migration using XPS. Catal. Today 2012, 184 (1), 78-82. 